\title{
Rejection of unsuitable substrata as a potential driver of aggregated settlement in the barnacle Balanus improvisus
}

\author{
K. M. Berntsson ${ }^{1, *}$, P. R. Jonsson ${ }^{1}$, A. I. Larsson ${ }^{1}$, S. Holdt ${ }^{2}$ \\ ${ }^{1}$ Tjärnö Marine Biological Laboratory, Department of Marine Ecology, Göteborg University, 45296 Strömstad, Sweden \\ ${ }^{2}$ Zoological Institute, University of Copenhagen, 2100 Copenhagen, Denmark
}

\begin{abstract}
Many marine invertebrate larvae have the capacity to reject or accept settlement sites based on a broad range of cues. Species-specific settlement responses to different cues are often inferred from final settlement choice in the field. Little is known about species-specific larval behaviour in response to different cues and, in particular, how the behaviour is linked to final settlement. Rejection of unsuitable substrata may be an important driving force that leads to aggregated settlement patterns. This study examines rejection responses in relation to surface attractiveness for settlement under field and laboratory conditions in the barnacle Balanus improvisus. The attractiveness for settlement was manipulated by varying surface texture in combination with crude extract from conspecific adults. Active rejection behaviour was examined as a function of surface texture and conspecific pheromones in the field and then related to behavioural responses under static and flowing conditions in the laboratory. Recruitment was heavily reduced on substrata with ribbed microtexture compared to smooth substrata and unaffected by crude extract from conspecific adults. On average, $28 \%$ of the cyprids that encountered smooth settlement panels recruited. The proportion of cyprids recruiting on 2 microtextured substrata after encounter was 5 and $1 \%$ respectively. In behavioural experiments cyprids showed higher motion speed and dispersal rate on textured substrata, which indicated less exploratory behaviour than on smooth substrata, while an addition of conspecific extract increased intensities of surface exploration on all types of substrata. Flume experiments further demonstrated that cyprids are more prone to leave textured substrata and that the rejection rate was independent of conspecific extract. This work emphasises the role of larval behaviour as a potentially powerful mechanism determining final recruitment pattern. It is concluded that the choice of settlement site is an important factor in the settlement process of B. improvisus, and the results suggest that surface topography may be a stronger cue for settlement than chemical attraction by conspecific adults in this species. This study presents an example whereby rejection of unsuitable substrata leads to an increased larval pool on adjacent substrata that are suitable for settlement, and indicates that this process may drive aggregated settlement in the barnacle B. improvisus.
\end{abstract}

KEY WORDS: Balanus improvisus $\cdot$ Barnacle $\cdot$ Cyprid $\cdot$ Larval behaviour $\cdot$ Settlement $\cdot$ Recruitment Surface texture $\cdot$ Larval ecology

\section{INTRODUCTION}

Settlement of new individuals into adult habitats has a major influence on population dynamics in marine communities. Settlement rate, the rate at which planktonic larvae establish permanent contact with the substratum, de- pends on the encounter rate of larvae with the shore or seabed (Gaines et al. 1985, Bertness et al. 1996), on suitable settlement substratum (Raimondi 1990, Minchinton \& Scheibling 1991, Pineda \& Caswell 1997), and on small-scale hydrodynamic and behavioural processes (Raimondi 1988a, Mullineaux \& Butman 1991, Raimondi \& Morse 2000). 
Most invertebrate larvae have the ability to choose a settlement site, and the final decision is influenced by stimuli perceived in the surrounding environment. Settlement of sessile marine invertebrates often results in aggregated settlement patterns. Aggregation of conspecifics through gregarious settlement is believed to be one of the main processes structuring communities of sessile marine invertebrates (e.g. Pawlik 1992, Toonen \& Pawlik 1994, Zimmer \& Butman 2000). Gregariousness is particularly prevalent among barnacles, for which chemical inducers derived from conspecific adults and larvae are regarded as the main cues that drive aggregated settlement (e.g. Knight-Jones 1953, Crisp 1974, Yule \& Walker 1985, Clare et al. 1994, Miron et al. 1996). Induced settlement by conspecific chemical cues has been shown for several barnacle species in laboratory experiments (e.g. Knight-Jones 1953, Crisp \& Meadows 1962, Rittschof et al. 1984, Dineen \& Hines 1992) and in the field (e.g. Raimondi 1988a, Jarrett 1997, Wright \& Boxshall 1999). However, cues other than the presence of conspecifics may contribute to aggregated settlement patterns. Physical cues associated with the substratum can influence settlement in barnacle larvae; these include surface topography (Crisp \& Barnes 1954), physico-chemistry of the substratum (Raimondi 1988b, Roberts et al. 1991) and flow regime (Mullineaux \& Butman 1991). Several non-conspecific biochemical cues are also known to affect the settlement of barnacles, e.g. compounds from other invertebrate species (Rittschof et al. 1985, Raimondi 1988a), bacterial films (Maki et al. 1988) and algae (Le Tourneux \& Bourget 1988, de Nys et al. 1995).

Cues may stimulate or deter settlement, and many studies of substrate-specificity indicate that larval acceptance and rejection strongly influence final settlement patterns (reviewed by e.g. Crisp 1974, Pawlik 1992). Hui \& Moyse (1987) suggested that rejection of unsuitable substrata increases the supply of prospective settlers to adjacent suitable substrata and thereby contributes to aggregated settlement patterns. Indeed, it was proposed that rejection of unsuitable substrata might be more important for the formation of aggregations than preferential settlement near conspecific adults. Responses to different cues have often been inferred from observations of the final settlement location, e.g. in relation to the presence or absence of conspecific chemical cues and surface complexity (e.g. Raimondi 1988a, Wethey 1986, Walters \& Wethey 1996). Although rejection of unsuitable substrata may be hypothesised from differences in final settlement intensity, more elaborate investigations of the active component of larval rejection require estimates of the number of larvae arriving and making initial contact with a substratum, and finally the number settling or leaving that substratum. Then, examination of the particular behaviour leading to rejection may explain if the process is active or passive. Walters (1992) and Lemire \& Bourget (1996) compared locations where larvae first contacted topographically complex substrata to sites with metamorphosed larvae, and suggested that choice of settlement site was best explained by larval selection. Responses in larval behaviour to different stimuli have often been observed in the laboratory (e.g. Hills et al. 1998, Walters et al. 1999, Berntsson et al. 2000a), but may not correspond to natural conditions in the field where larvae are subjected to several stimuli simultaneously (e.g. Hills et al. 2000). As advocated by Zimmer \& Butman (2000), studies of larval responses should be performed in the presence of major stimuli experienced in the field to avoid serious artefacts. Laboratory studies have, nevertheless, improved our understanding of larval sequential behaviour leading to final settlement (e.g. Lagersson \& Høeg 2002) and how they detect chemical signals in their environment (Zimmer-Faust \& Tamburri 1994, Clare 1995, Zimmer \& Butman 2000). Few studies have focused on the active behavioural components leading to rejection of substrata and what consequences rejection may have on the settlement rate on suitable adjacent substrata. Indirect methods to indicate rejection of different substrata have been used by Rittschof et al. (1984) and Holm (1990). Both studies estimated responses in larval behaviour of Balanus amphitrite by measuring the time it took larvae to pass through tubes under low-flow conditions. Rittschof et al. (1984) showed that the time required to pass through the tubes was influenced by the presence of conspecific extract and the age of the cyprids, and Holm (1990) found that the passage time in tubes with different materials was influenced by the genetical background of the larvae. More direct studies of larval rejection were performed by Mullineaux \& Butman (1991), who explored larval initial contact and substrata as a function of flow velocity. In their laboratory flume, cyprids rejected surfaces more frequently in a fast flow $\left(10 \mathrm{~cm} \mathrm{~s}^{-1}\right)$ than in a slow flow $\left(5 \mathrm{~cm} \mathrm{~s}^{-1}\right)$ but it was not possible to distinguish between passive detachment and active rejection (Mullineaux \& Butman 1991). Eckman et al. (1990) assessed the drag forces associated with cyprid detachment from surfaces in a flume, and found that the forces required were positively correlated with the duration of antennular attachment (Eckman et al. 1990).

The barnacle Balanus improvisus shows aggregated recruitment patterns on smooth settlement panels in the field, while recruitment is strongly reduced on adjacent textured surfaces (Berntsson et al. 2000a,b, Berntsson \& Jonsson 2003). Differences between smooth and textured panels were best explained by 
responses in larval behaviour (Berntsson et al. 2000a). However, cues or processes that contribute to aggregated settlement in $B$. improvisus have not been investigated in field experiments. Dineen \& Hines (1992) showed that cyprids of $B$. improvisus are stimulated to settle in the presence of extracts from conspecific and congeneric adults in a laboratory study. In their study, settlement was higher in containers with conspecific than with congeneric cues and was lowest in untreated containers.

Differences in recruitment patterns of Balanus improvisus on panels differing in surface texture cannot be explained by the presence of conspecific adults. In the present study, we instead explored the effect of larval rejection of unsuitable substrata as a potential process leading to aggregated settlement. Our approach was to estimate the relative role of larval behaviour and active rejection for patterns of recruitment in the barnacle $B$. improvisus. The temporal variability in contact rate and recruitment rate was measured on substrata inducing different larval behaviour. Surface texture was presented as a negative cue, untreated smooth panels as an independent treatment lacking a negative cue, and adult extract as a positive cue of conspecific presence. Behavioural differences in response to these cues were first established and quantified in laboratory experiments. The field experiments were then designed to test the relative effects of surface texture and conspecific extract on recruitment and to estimate active rejection of unattractive substrata. In particular, we wanted to (1) quantify responses in larval behaviour to the different cues under static and flowing conditions, and (2) determine if recruitment reflects the relative strength of the cues in the field. The approach was to link behavioural responses to final choice of settlement site in the field and to test (1) if chemical cues from conspecific adults are the major mediator of aggregated settlement patterns, or (2) if rejection of unsuitable substrata may contribute to aggregations on adjacent substrata that are suitable for settlement.

\section{MATERIALS AND METHODS}

Study area and organism. Field studies were performed in the Tjärnö archipelago $\left(58^{\circ} 53^{\prime} \mathrm{N}, 11^{\circ} 8^{\prime} \mathrm{E}\right)$, at the northern part of the Swedish Skagerrak coast. The Skagerrak Sea is a transitional area between the Baltic Sea and the North Sea and is characterised by a complex hydrography due to dynamic anticlockwise circulation and the mixing of several different water masses (Gustafsson \& Stigebrandt 1996).

The barnacle Balanus improvisus is the dominant fouler on artificial substrata in the study area (Bernts- son \& Jonsson 2003). B. improvisus was introduced to Scandinavian waters during the 19th century and is now common in salinities from 34 psu on the Norwegian west coast to around 3 psu in the Baltic Sea (Foster 1987). On the Swedish west coast, $B$. improvisus is found on most natural substrata, although it seems to have a preference for artificial substrata (Berntsson et al. 2000b, Berntsson \& Jonsson 2003). In Swedish waters, $B$. improvisus reproductive activity occurs continuously during the summer and early autumn. Settlement and recruitment normally occur from June to October with peak settlement from July to September (Berntsson et al. 2000a, Berntsson \& Jonsson 2003), depending on water temperature. The distribution of cyprids in the water column depends on the strength of the vertical mixing in the surface layer, but under normal summer conditions $B$. improvisus settles most abundantly within the top $3 \mathrm{~m}$ of the water column, although occasional settlement has been recorded down to $7 \mathrm{~m}$ depth (Berntsson et al. 2000a).

Contact and settlement rates on substrata of different attractiveness. In a field experiment, surface texture on settlement panels was manipulated to evoke gradual responses in Balanus improvisus recruitment. Previous studies had shown that surface texture is a negative cue for settlement in cyprids of $B$. improvisus, and that the settlement response varies with topographic scale (Berntsson et al. 2000a,b). We used 1 smooth and 2 micro-ribbed substrata of similar geometry but of different size to create substrata with decreasing attractiveness for settlement. Surface treatments were untreated polymethyl-methacrylate (PMMA) panels (smooth), PMMA panels with a ribbed, peaked structure of $64 \mu \mathrm{m}$ height and width at the base (Riblet 1), and PMMA panels with a ribbed, peaked structure of $352 \mu \mathrm{m}$ height and $134 \mu \mathrm{m}$ width at the base (Riblet 2) (for SEM micrographs and topographical characterisations see Berntsson et al. 2000b). Manufacturing of riblet-structures in PMMA involved curing liquid methyl-methacrylate (mixed with 3.5\% catalyst hardener) in inverse vinylpolysiloxane moulds. The master moulds were pre-fabricated polyvinylidenefluoride (PVDF, Riblet 1) and polyvinylchloride (PVC, Riblet 2) riblet films (Berntsson et al. 2000b) that were first replicated into vinyl polysiloxane dentalimpression material (Provil ${ }^{\circledR}$ novo, Type 3, low-consistency; Heraeus Kulzer, EN 24823) and the replica were subsequently used as moulds for curing PMMA. Production of smooth test panels was similarly carried out by replicating a smooth glass substratum into vinyl polysiloxane and use the smooth replica as a mould for curing PMMA. Methyl-methacrylate was cured in UV radiation $(250 \mathrm{~nm})$ for 30 min and then in ambient sunlight for $1 \mathrm{wk}$. The vinylpolysiloxane mould was then removed and the PMMA casts were heated for $5 \mathrm{~min}$ at 
$90^{\circ} \mathrm{C}$ and $1 \mathrm{~h}$ at $60^{\circ} \mathrm{C}$ in a desiccator. After heating, the panels $(60 \times 60 \mathrm{~mm})$ were placed in running seawater for $1 \mathrm{wk}$ prior to use.

Dineen \& Hines (1992) have shown that substrata coated with extract from conspecific adults stimulate settlement in cyprids of Balanus improvisus. Therefore, extract from conspecific adults was included as a treatment factor to investigate the relative effects of microtexture and extract on recruitment separately and in combination. Crude extract from conspecific adults was prepared as described in Rittschof et al. (1984) and frozen at $-18^{\circ} \mathrm{C}$ until use.

This study was also designed to estimate the proportion of cyprids that settled onto substrata after contact as a function of surface attractiveness. Initial surface contact of cyprids was determined by coating settlement panels with silicone grease ('Hochvakuum Fett Mittel', Wacker) to prevent larvae from leaving the substratum after initial contact (Walters 1992). Subsets of all surface treatments were coated with extract and vacuum silicone grease, respectively, and then airdried for $12 \mathrm{~h}$ prior to use.

Test panels were fixed randomly to 2 aluminium frames, with 6 replicates of each panel treatment (smooth, Riblet 1 and Riblet 2: untreated topography, topography coated with adult crude extract and topography coated with silicone grease), and were then submerged to a depth interval of 1 to $2 \mathrm{~m}$. Frames were submerged from a stationary raft located in a $15 \mathrm{~m}$ deep bay with weak water currents $\left(0.05 \mathrm{~m} \mathrm{~s}^{-1}\right)$ outside Tjärnö. Panel treatments were submerged between 3 and 7 July, 24 and 31 July, 2 and 7 August, 11 and 16 August, and finally between 17 and 22 August 2000. After field exposure, the number of cyprids recruited on untreated and extract-treated topographies and trapped on the greased panels was counted using a dissecting microscope. Furthermore, 6 replicates of each untreated smooth, Riblet 1 and Riblet 2 panels were submerged between 3 July and 1 September 2000 to test the effect of microtexture on barnacle recruitment over a longer time interval.

A separate experiment was carried out to check that cyprids trapped on silicone grease remained after several days of field exposure. Cyprids were first allowed to make contact with 8 panels prepared with silicone grease in the laboratory for $24 \mathrm{~h}$, and then the number of cyprids trapped on all panels was counted before exposure in the field. Finally, the number remaining trapped was counted on duplicate panels removed after 2, 4, 6 and $8 \mathrm{~d}$ of submersion in the field respectively.

In contrast to the results obtained by Dineen \& Hines (1992), conspecific crude extract prepared as described in Rittschof et al. (1984) had no obvious effect on Balanus improvisus recruitment in the present field experiment. New field and laboratory experiments were therefore conducted in 2002 with crude extracts prepared as in Matsumura et al. (1998a) and a new preparation of freshly homogenised adults (Raimondi 1988a). Preparation of crude extract involved crushing adults in Tris- $\mathrm{HCl}$, filtering the homogenate through gaze followed by centrifugation, and finally filtering the supernatants (Whatman No. 5). The preparations of homogenised extract involved crushing adults in sterile filtered seawater and then filtering the homogenate through gauze. Protein concentrations of the extracts were $0.9 \mathrm{mg} \mathrm{ml}^{-1}$, as determined by the Bradford method with Coomassie Brilliant Blue and serum bovine albumin as the standard protein. Crude and homogenised extracts were then kept in the freezer at $-18^{\circ} \mathrm{C}$ until use. Treatments in the field experiment included PMMA panels coated with crude and homogenised extracts (evaporated on substrata), and crude extract mixed in Phytagel ${ }^{\mathrm{TM}}$ (Sigma, Lot 22K0055), all at a concentration of $370 \mathrm{mg}$ protein $\mathrm{m}^{-2}$. Crude extract was cured in Phytagel. Treatments were allowed to dry for $12 \mathrm{~h}$ at room temperature in a fume cupboard prior to exposure in field trials. Finally, recruitment was compared with smooth untreated PMMA panels and PMMA panels prepared with Phytagel as controls. Test panels were fixed randomly to 2 aluminium frames, 4 replicates of each panel treatment (PMMA control, Phytagel control, PMMA with evaporated crude extract, Phytagel with crude extract and PMMA with evaporated homogenised extract) and then submerged to a depth of 1 to $2 \mathrm{~m}$. Panel treatments were submerged between 6 and 11 September and between 13 and 20 September 2002. After field exposure, the number of cyprids recruited on panels was counted. The laboratory experiment included treatments of crude extract and homogenised adults (prepared as above). Crude extract was cured in Phytagel at concentrations of 1 and $11 \mathrm{mg} \mathrm{m}^{-2}$ in polystyrene containers ( $\varnothing 48 \mathrm{~mm}$, Nunc 536757), and crude and homogenised extracts were evaporated at serial concentrations of $1,11,111,370$ and $1111 \mathrm{mg} \mathrm{m}^{-2}$ in containers. Settlement was compared between containers treated with different extracts and concentrations and controls in a laboratory assay. Polystyrene containers with Tris- $\mathrm{HCl}$ evaporated and cured in Phytagel were used as controls for treatments of crude extract, while untreated containers were controls to treatments of homogenised extract. We supplied 3 replicate containers per treatment with $30 \mathrm{ml}$ sterile filtered seawater and 453 -d-old cyprids (reared in the laboratory as described below), respectively. Settlement and metamorphosis were examined after $6 \mathrm{~d}$ under a dissecting microscope.

Cyprid behaviour on substrata of different attractiveness in still and flowing water. In laboratory ex- 
periments we investigated the exploration behaviour of cyprids exposed to substrata with different surface attractiveness. Cypris larvae of the barnacle Balanus improvisus were obtained from a stock of adult individuals maintained at the Tjärnö Marine Biological Laboratory, and were reared in batch culture on the diatoms Skeletonema costatum and Thalassiosira pseudonana at $27^{\circ} \mathrm{C}$ as described in Berntsson et al. (2000a). The cyprid stage was reached $6 \mathrm{~d}$ after hatching. Cyprids were then stored in the dark at room temperature $\left(21^{\circ} \mathrm{C}\right)$. Previous studies had indicated that the intensity of surface contact and exploratory behaviour diminish in B. improvisus cyprids when stored $\left(2\right.$ to $3 \mathrm{~d}$ ) at lower temperatures ( 4 to $13^{\circ} \mathrm{C}$ : authors' pers. obs.). Cyprid behaviour was monitored on Days 2 and 3 after the last moult, as settlement is most intense in this age group (K. M. Berntsson pers. obs.). The response in exploratory behaviour to different surface treatments was examined in still and flowing water. Collection of larvae and experiments in still water were carried out during May and June 2000, and flume studies were carried out during December and January 2000-2001. Substrata with different attractiveness for settlement were prepared on PMMA panels (smooth, Riblet 1 and Riblet 2): untreated topography and topography coated with adult crude extract as described above for the field experiment.

In the still-water experiments, 4 replicate arenas of each topography (smooth, Riblet 1 and Riblet 2) were prepared with a plastic frame enclosing each arena $(30 \times 30 \mathrm{~mm})$. All replicates were soaked in distilled water $(1 \mathrm{wk})$ and then split into untreated and treated topographies as described above. Each trial included untreated topographies and topographies prepared with extract from conspecific adults placed in petri dishes with $20 \mathrm{ml}$ of sterile-filtered seawater $(30 \%)$. A cyprid that performed surface exploration in the storage beaker was haphazardly collected (from approximately 5000 individuals) and transferred to the enclosed arena $10 \mathrm{~min}$ before recording. Cyprids that did not show any exploratory behaviour during this time were replaced. Cyprid movements in the arenas on different surface treatments were recorded with a video camera (Mintron CCD Camera, Olympus $50 \mathrm{~mm}$ lens) with background illumination directed through the transparent PMMA. Digitised video images from the camera were sampled at $1 \mathrm{~Hz}$ and analysed in real time with image-analysis software (IP Lab for Apple Macintosh). The cyprid position, cyprid long and short axes and the angle of major axis were recorded and stored on file. Cyprid behaviour on each surface treatment was recorded for 12 separate individuals from 3 different batches at Days 2 and 3. If a cyprid explored the wall of the arena instead of the target substratum or was trapped in occasional impurities on the substra- tum, the recording was terminated and resumed with a new individual. Substrata were washed in hot water $\left(75^{\circ} \mathrm{C}\right)$ between daily recordings; and in detergents with citric acid (280 ml Extran AP22, pH 2.21, in 3.5 l $\mathrm{H}_{2} \mathrm{O}$ ) followed by rinsing in hot water and soaking in distilled water between weekly recordings (substrata with and without adult extract were kept separate at all times). The path of each cyprid was tracked for $7.5 \mathrm{~min}$, resulting in a database of ca. 450 positions. From each path we calculated the speed, fractal dimension (Sugihara \& May 1990) and path sinuosity (Bovet \& Benhamou 1988). Fractal dimension was calculated by the dividers method (Sugihara \& May 1990) on walking tracks. Sinuosity expresses the intensity of direction changes, and is assumed to correlate with close exploration, i.e. the behavioural stage indicative of an attractive substratum (Crisp 1974).

Exploratory behaviour in relation to surface treatment and flow was studied in a laboratory flume, consisting of a Plexiglas tank $1.7 \times 0.2 \times 0.1 \mathrm{~m}$ with a PVC return pipe (diameter $0.13 \mathrm{~m}$ ). Seawater was added to the flume to a depth of $2 \mathrm{~cm}$. Dye was added to the flume and the velocity gradient and turbulence at different flow speeds were measured from video recordings of particle trajectories. The water passing over the working section was fully turbulent, and the boundary-layer thickness $(\delta)$ is then growing as (Schlichting 1979):

$$
\delta=0.37 x\left(\frac{U_{\infty} X}{v}\right)^{-0.2}
$$

In a free-stream flow speed of 2 to $8 \mathrm{~cm} \mathrm{~s}^{-1}$, the boundary layer was fully developed at the working section located $1 \mathrm{~m}$ from the entrance (a velocity of $4 \mathrm{~cm} \mathrm{~s}^{-1}$ gives a boundary-layer thickness of $4.4 \mathrm{~cm}$ ).

Water temperature was maintained at $21^{\circ} \mathrm{C}$ during the experiments. Close observation of cyprids exploring a substratum subjected to flow showed that up to a free-stream velocity of $4 \mathrm{~cm} \mathrm{~s}^{-1}$ they continued to walk across the substratum, apparently unimpeded by the flow (Jonsson et al. 2004). At about $8 \mathrm{~cm} \mathrm{~s}^{-1}$ cyprids became motionless, with their antennulae attached to the bottom substratum (Jonsson et al. 2004, see also Walters et al. 1999). Settling behaviour in flume flow was studied at a free-stream velocity of $4 \mathrm{~cm} \mathrm{~s}^{-1}$, a velocity that allowed us to quantify the proportion of cyprids that left a substratum after exploration. Exploratory behaviour was studied on smooth and riblet surfaces with and without adult extract (PMMA, $60 \times 60 \mathrm{~mm}$, produced as described for the field study). We placed 1 of the substrata in the flume working section (riblets arranged in the direction of the flow). Substrata with and without adult extract were run in separate trials. The panels were illuminated from below by a lamp placed underneath the working section. From ca. 5000 individuals, 40 to 50 cyprids were haphaz- 
ardly collected and deposited near the centre of each substratum. The relatively small panels motivated a larger initial amount of cyprids in this experiment because of the risk of cyprids accidentally leaving the panels while swimming or walking. The cyprids were allowed to acclimate to the substrata for 5 min in still water. The remaining cyprids were then counted through a dissecting microscope, and the flow velocity was set to $4 \mathrm{~cm} \mathrm{~s}^{-1}$, the flow gradually increased from stagnant to the chosen speed over $1.5 \mathrm{~min}$. The number of cyprids exploring the substrata was counted again after 2, 5, 10, 15 and 20 min in flowing water. We used 2 panels of each combination of surface texture and adult extract. For each panel, 3 replicate experiments were run with cyprids from 2 different batches at Days 2 and 3. Between runs the panels were washed in hot $\left(75^{\circ} \mathrm{C}\right)$ water. The sequence of panels was randomly selected. In the analysis, the proportion of cyprids left on each substratum after 5 min was used as the dependent variable.

Statistical treatment. If not otherwise indicated, data are reported as means with $95 \%$ confidence intervals. Analysis of variance (ANOVA) was used to test for differences in recruitment and behaviour among surface treatments. The orthogonal factors considered in the analyses of recruitment included surface microtexture ('topography'), extract from conspecific adults ('extract') and weekly interval of submersion ('week'). Analyses of behaviour included the factors 'topography' and 'extract'. All factors were considered as fixed in the analyses except week, which was considered as random. A posteriori comparisons were performed using the Student-Newman-Keuls (SNK) procedure, and tests for homogeneity of variances were performed using Cochrans's $C$-test (Winer et al. 1991). Data sets on recruitment showed heteroscedasticity and were accordingly log-transformed $\left(\log _{10}\right)$ prior to the ANOVA. This also implies that interactions among factors should be interpreted on a proportional scale. For the field experiments, data were log-transformed as $\log _{10}($ recruitment +1$)$. Ratios of recruitment were transformed as $\sin ^{-1}(\sqrt{\text { ratio }})$. In all statistical analyses, a Type I error $(\alpha)$ of 0.05 was used.

\section{RESULTS}

\section{Field experiments}

Recruitment on smooth versus microtextured substrata

Balanus improvisus recruitment on smooth and microtextured PMMA panels was compared after a longterm exposure in the Tjärnö archipelago from July to September 2000. The number of recruits decreased

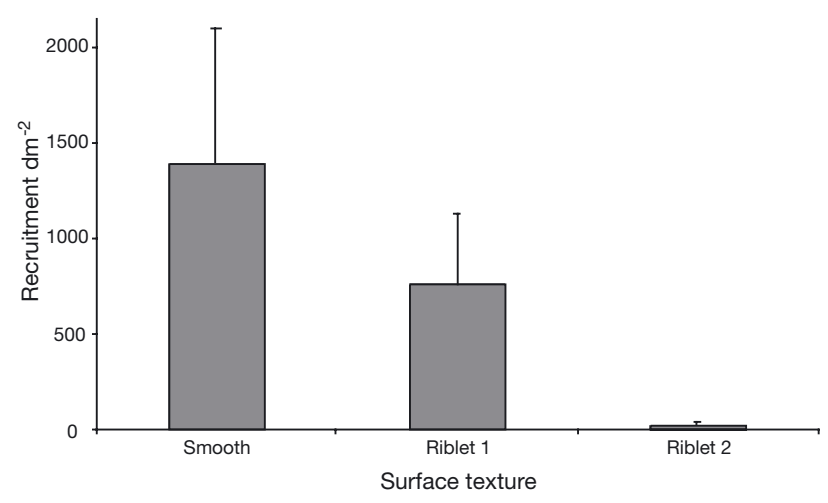

Fig. 1. Balanus improvisus. Recruitment (ordinate: mean nos. $\mathrm{dm}^{-2}+95 \% \mathrm{CI}, \mathrm{n}=6$ ) as a function of surface texture over 2 mo (July to September 2000)

gradually from smooth substrata to Riblet 1 (small riblet) and Riblet 2 (large riblet) treatments (Fig. 1). Although all surface textures differed from each other (ANOVA, $F_{2,15}=96.4, \mathrm{p}<0.05$, SNK, $\mathrm{p}<0.05$ ) recruitment was particularly low on Riblet 2 (large riblet) panels $\left(20 \pm 15\right.$ ind. $\mathrm{dm}^{-2}$ ) compared to smooth panels (1392 \pm 706 ind. $\mathrm{dm}^{-2}$, Fig. 1). Furthermore Riblet 1 (small riblet) panels showed intermediate recruitment intensity (764 \pm 366 ind. $\mathrm{dm}^{-2}$, Fig. 1), which indicates a gradual recruitment response as a function of riblet size and geometry.

\section{Recruitment at weekly intervals}

Recruitment of Balanus improvisus on microtextured substrata separately and in combination with extract from conspecific adults was tested in 5 short-term exposures (5 to 7 d) during July and August 2000. Short-term exposure of microtextured surfaces further demonstrated that the effect of surface texture on $B$. improvisus recruitment was consistent also at shorter timescales (Fig. 2a, Table 1). The presence of adult extract on smooth and microtextured substrata had no detectable effect on recruitment rates, as shown by the non-significant interaction (ANOVA, $F_{2,8}=1.7, \mathrm{p}>0.05$ ) (Fig. 2b, Table 1). The ANOVA detected significant second- and first-order interactions with the random factor week (Table 1). Inspection of the interactions among topography, adult extract and week shows that the qualitative difference between smooth and the 2 sizes of surface topography changed slightly between weeks when adult extract was present (Fig. 2)

The effects of conspecific cues on Balanus improvisus recruitment were further tested in 2 short-term exposures (5 to 7 d) during September 2002. Panel treatments included crude extract evaporated on panels, extract cured in Phytagel, and homogenate of adult 

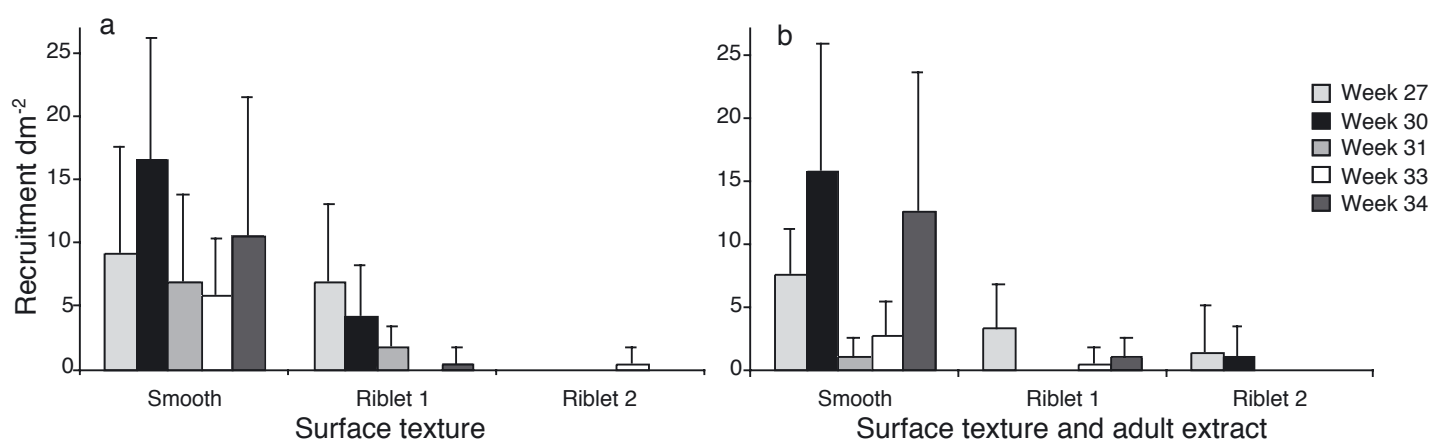

Fig. 2. Balanus improvisus. Weekly recruitment (mean nos. $\mathrm{dm}^{-2}+95 \% \mathrm{CI}, \mathrm{n}=6$ ) on polymethyl-methacrylate (PMMA) panels with (a) 2 scales of microtexture compared to smooth control, and (b) surface texture in combination with extract from conspecific adults, during Weeks 27, 30, 31, 33 and 34 in July and August 2000

Table 1. Balanus improvius. Three-factor ANOVA testing effects $\left(\log _{10}\right.$-transformed) of extract from conspecific adults, topography and week of exposure on recruitment. Adult extract: panels with and without extract from adult barnacles. Topography: 2 microtextures and 1 smooth panel; Week: 5 weeks (Weeks 27, 30, 31, 33 and 34 in July and August 2000) with panels exposed for $1 \mathrm{wk}$

\begin{tabular}{|lrrrrl|}
\hline Source & df & MS & $F$ & $\mathrm{p}$ & Error term \\
\hline Adult extract (E) & 1 & 0.666 & 3.135 & 0.151 & $\mathrm{E} \times \mathrm{W}$ \\
Topography (T) & 2 & 9.712 & 29.006 & 0.0002 & $\mathrm{~T} \times \mathrm{W}$ \\
Week (W) & 4 & 0.745 & 9.553 & 0.0001 & Residual \\
$\mathrm{E} \times \mathrm{T}$ & 2 & 0.297 & 1.711 & 0.241 & $\mathrm{E} \times \mathrm{T} \times \mathrm{W}$ \\
$\mathrm{E} \times \mathrm{W}$ & 4 & 0.212 & 2.724 & 0.032 & Residual \\
$\mathrm{T} \times \mathrm{W}$ & 8 & 0.335 & 4.293 & 0.0001 & Residual \\
$\mathrm{E} \times \mathrm{T} \times \mathrm{W}$ & 8 & 0.174 & 2.226 & 0.029 & Residual \\
Residual & 150 & 0.078 & & & \\
\hline
\end{tabular}

tissues. As in the study in 2000, there was no effect of conspecific adult extracts on recruitment compared to untreated PMMA panels (ANOVA, $F_{4,15}=$ 1.2, $\mathrm{p}>0.05$, Fig. 3). Recruitment tended to be lower in treatments with extract in Week 37 than in the previous week, however, this difference was not significant (ANOVA, $F_{1,38}=3.7, \mathrm{p}>0.05$, Fig. 3). Settlement responses to different preparations and concentrations of conspecific extracts in the laboratory assay corresponded to those in the field experiment. There was no stimulating effect of adult extracts on settlement in the assay; instead, settlement seemed to decrease with increasing concentrations of crude and homogenised extracts $\left(\right.$ ANOVA, $F_{6,14}=6.1, \mathrm{p}<0.05$, SNK, $\mathrm{p}<0.05$, Fig. 4).

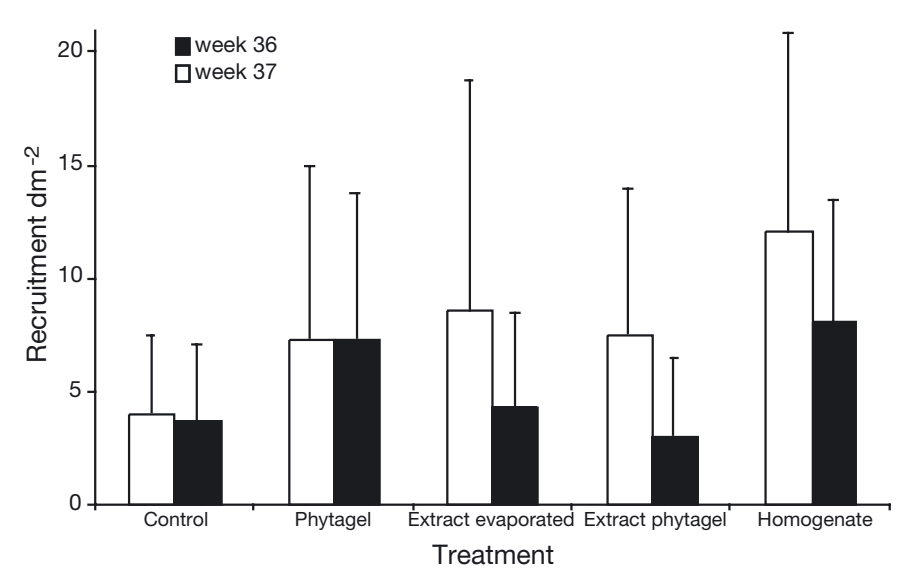

Fig. 3. Balanus improvisus. Weekly recruitment (mean nos. $\mathrm{dm}^{-2}+95 \% \mathrm{CI}, \mathrm{n}=4$ ) on PMMA panels coated with conspecific crude extract (Extract evaporated), extract mixed in Phytagel (Extract phytagel) and homogenate of adult tissue compared to untreated PMMA (Control) and panels coated with

Phytagel during Weeks 36 and 37 in September 2002

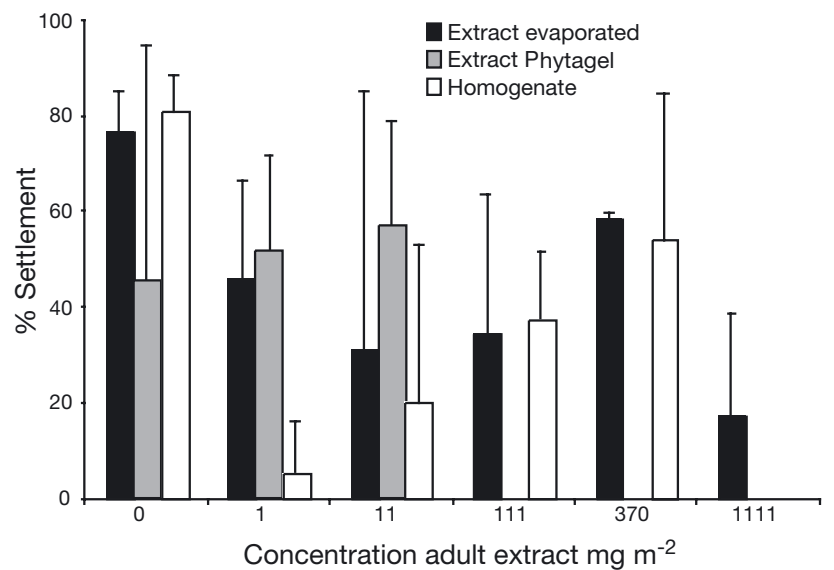

Fig. 4. Balanus improvisus. Settlement (mean percentage settled $+95 \%$ CI, $\mathrm{n}=3$ ) in polystyrene dishes prepared with different concentrations of evaporated crude extract, crude extract cured in Phytagel and homogenate of adult tissue compared to control containers in September 2002. Controls (0 $\mathrm{mg} \mathrm{m}^{-2}$ on $\mathrm{x}$-axis) were evaporated Tris- $\mathrm{HCl}$ (black bars), Tris- $\mathrm{HCl}$ cured in Phytagel (grey bars) and containers untreated (white bars) 


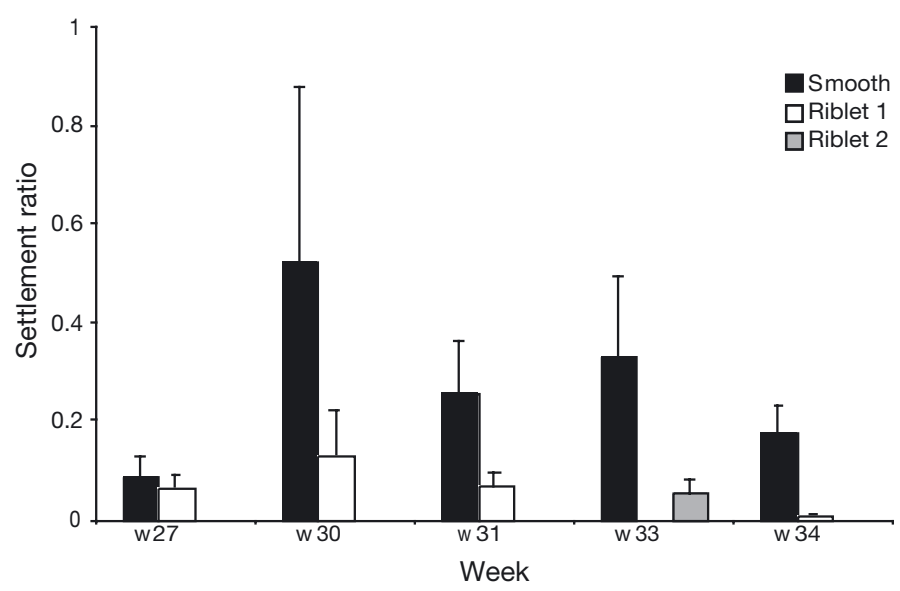

Fig. 5. Balanus improvisus. Ratio (ordinate) of recruitment rate to contact rate, showing data for initial surface contact and weekly recruitment during Weeks 27, 30, 31, 33 and 34 in July and August 2000
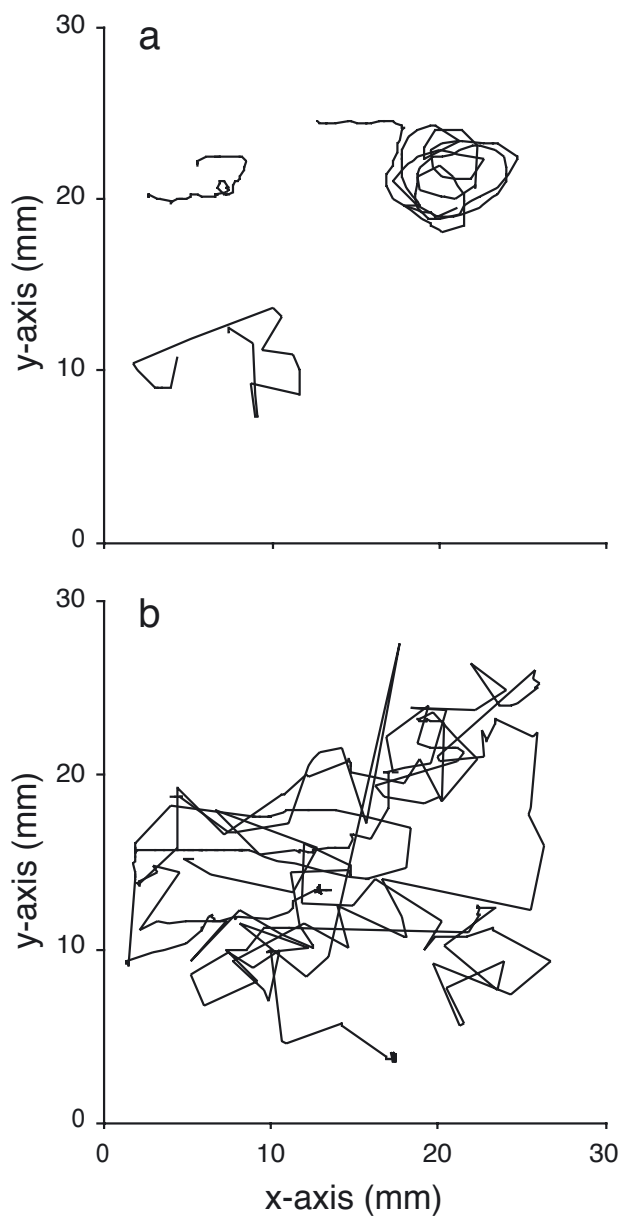

Fig. 6. Balanus improvisus. Movement paths of cyprids on (a) smooth surfaces and (b) microtextured Riblet 2 surface in behavioural studies. Each graph shows typical examples of total movements of 3 individuals

\section{Contact and recruitment rates}

Evaluation of contact rate on panels with silicone grease was run parallel to the 5 short-term incubations on the different surface textures. Average settlement ratio, the ratio of recruitment rate to contact rate, was $0.28 \pm 0.19$ on smooth settlement panels and $0.05 \pm 0.06$ and $0.01 \pm 0.03$ on Riblet 1 and Riblet 2 substrata, respectively. Contact rate and settlement ratio on smooth substrata varied between weeks (ANOVA, $F_{4,25}=22.2, \mathrm{p}<0.05$ and $F_{4,25}=8.8, \mathrm{p}<0.05$, respectively). Cyprids made most contact with substrata in Week 27 and least contact during Week 33 (SNK, $\mathrm{p}<0.05)$. Settlement ratio was lowest in Week 27 (Fig. 5, SNK, p < 0.05).

No significant relationship was found between contact rate or settlement ratio with recruitment rate for the different surface treatments (regression, $\mathrm{p}>0.05$ ).

\section{Larval behaviour}

Fig. 6 shows examples of recorded cyprid paths on the smooth and the topographic Riblet 2 substratum. Cyprids moved more continuously and randomly over the Riblet 2 surface (Fig. 6b). The speed of cyprid movement was significantly slower on the smooth substratum and the sinuosity was higher (Fig. 7, ANOVA, $\left.F_{2,60}=3.4, F_{2,42}=5.3, \mathrm{p}<0.05\right)$. This indicates a higher
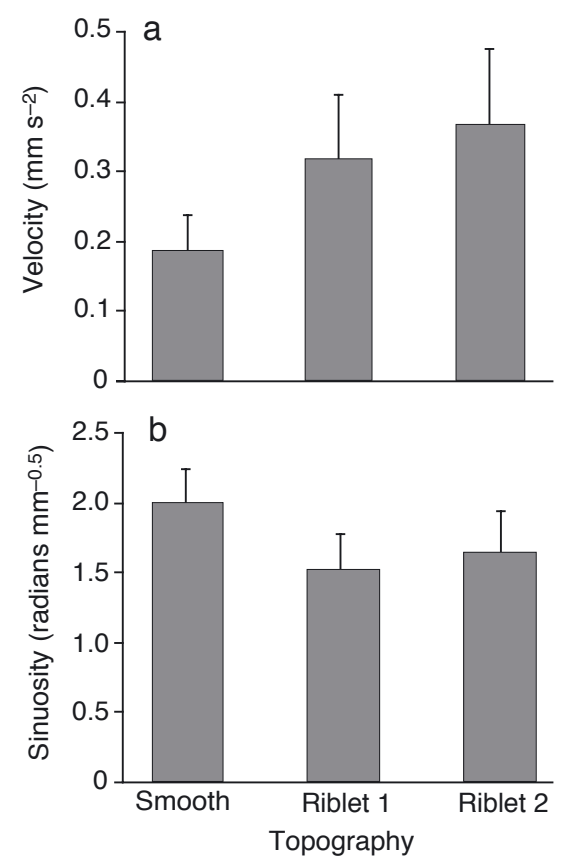

Fig. 7. Balanus improvisus. (a) Velocity (mean $+95 \% \mathrm{CI}, \mathrm{n}=$ 21 ) and (b) sinuosity (radians $\mathrm{mm}^{-0.5}$, mean $+95 \% \mathrm{CI}, \mathrm{n}=15$ ) of cyprid movements on smooth and microtextured surfaces 


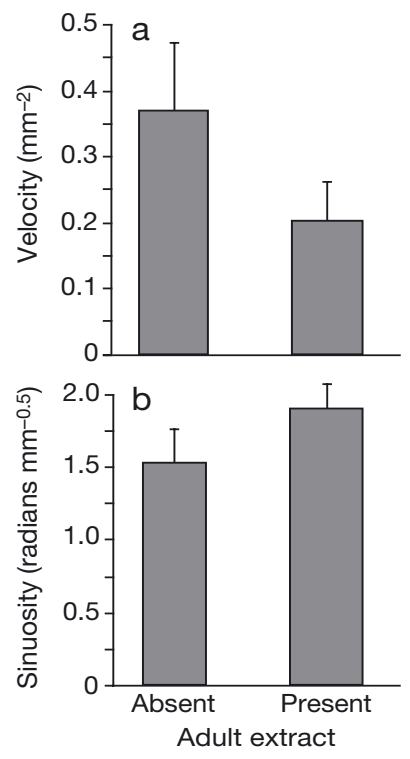

Fig. 8. Balanus improvisus. (a) Velocity (mean $+95 \% \mathrm{CI}, \mathrm{n}=$ 31 ) and (b) sinuosity (radians $\mathrm{mm}^{-0.5}$, mean $+95 \% \mathrm{CI}, \mathrm{n}=15$ ) of cyprid movements on surfaces treated with extract from conspecific adults

frequency of close exploration on the smooth substratum. The presence of conspecific crude extract decreased the speed of movement (Fig. 8a, ANOVA, $\left.F_{1,60}=6.8, \mathrm{p}<0.05\right)$ and increased the sinuosity of the path on both smooth and riblet substrata (Fig. 8b, ANOVA, $\left.F_{1,42}=14.5, \mathrm{p}<0.05\right)$. No difference in path fractal dimension was detected between the surface treatments (ANOVA, $F_{2,42}=1.07, \mathrm{p}>0.05$ ).

Observations of settlement behaviour in a flume flow allowed us to quantify the proportion of cyprids that left a substratum after exploration. The disappearance of cyprids may reflect either active rejection or passive detachment. Active rejection of smooth and riblet substrata were studied at a flow speed of $4 \mathrm{~cm} \mathrm{~s}^{-1}$. The number of cyprids exploring substrata decreased at a higher rate on the riblet 2 substratum than on the smooth substratum with time (Fig. 9). After 5 min in flowing water, the proportion of cyprids remaining on the riblet 2 substrata was significantly lower (ANOVA, $\left.F_{1,16}=12.8, \mathrm{p}<0.05\right)$ than on the smooth substrata (Fig. 10a). This difference indicates a higher propensity of cyprids to leave riblet substrata. We found no effect of the crude extract in the flume experiments (ANOVA, $F_{1,16}=3.4, \mathrm{p}>0.05$, Fig. 10b).

\section{DISCUSSION}

The present study tested the hypothesis that active settling behaviour may contribute to differences in recruitment on small spatial scales. Recruitment, in the

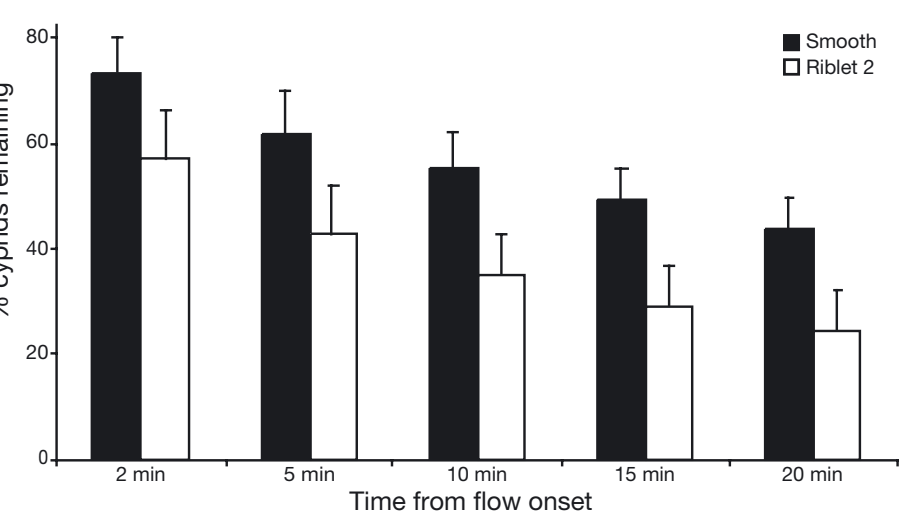

Fig. 9. Balanus improvisus. Proportion (mean $+95 \%$ CI, $\mathrm{n}=12$ ) of exploring cyprids remaining attached to a smooth and to a microtextured surface after different periods of time

field and in the laboratory, was considerably lower on riblet than on smooth substrata. Less exploratory behaviour occurred on the riblet substrata, as indicated by a higher speed of movement and higher dispersal rate compared to smooth surfaces. Flume experiments further demonstrated that cyprids are more prone to leave riblet substrata. The behavioural studies thus strongly suggest that cyprids actively rejected the riblet surfaces. In the field, adjacent panels differing in

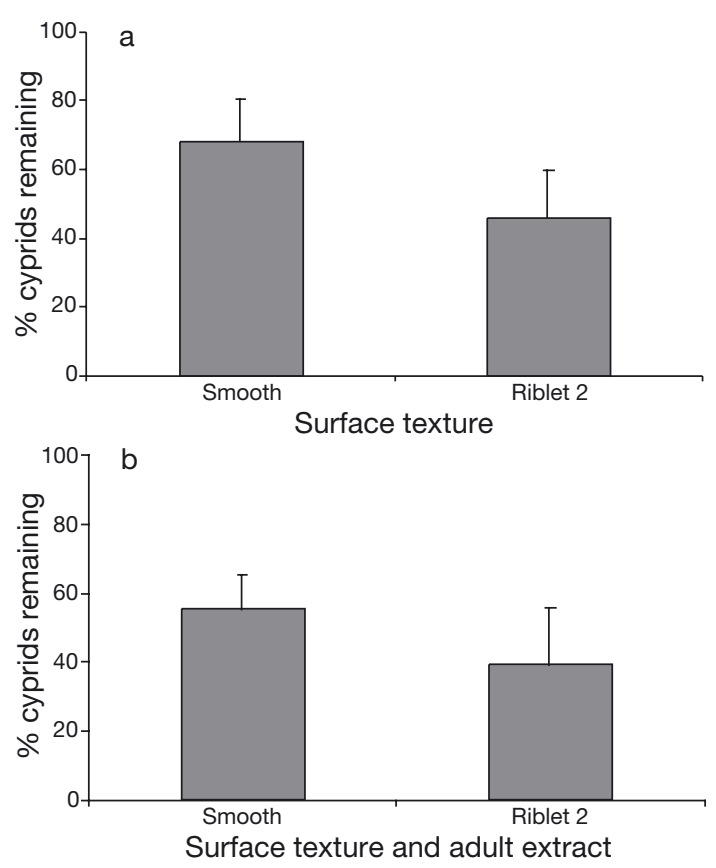

Fig. 10. Balanus improvisus. Proportion (mean $+95 \% \mathrm{CI}, \mathrm{n}=6$ ) of exploring cyprids remaining attached (a) to a smooth and to a microtextured surface, and (b) to surfaces treated with extract from conspecific adults $(n=6)$ after $5 \mathrm{~min}$ at a flow speed of $4 \mathrm{~cm} \mathrm{~s}^{-1}$ 
surface texture showed dramatic differences in recruitment rate. Contact rates were similar for the smooth and the riblet substrata and the percentages of cyprids encountering the panels that finally settled were 27, 5 and $1 \%$ for smooth and the 2 repellent riblet substrata, respectively. We interpret this difference as a consequence of active rejection of the textured substrata. Similar results were found in Berntsson et al. (2000a), who tested a wide range of surface textures. Reduced recruitment on textured substrata could be due to physical constraints, e.g. inability to make initial contact with the substratum or reduced adhesion at final settlement. There was a decline in recruitment from smooth to the 2 different types of riblets used, and this response was independent of the exposure interval (Figs. 1 \& 2a). The intermediate recruitment on the Riblet 1 substratum indicates that most cyprids choose not to recruit on structured substratum even when the geometry of the substratum physically allows adhesion and fixation. Further support of active larval behaviour in response to surface topography was reported by Berntsson et al. (2000a), who found that cyprids settled more often on a smooth part of a substratum than on a textured part in choice experiments. These results are in further agreement with those of previous behavioural studies in which, after exploration, cyprids rejected textured substrata more often than smooth substratum (Berntsson et al. 2000a).

The cyprid contact rate and the settlement ratio showed no relationships with final recruitment on the different surface treatments in the present study, a result that may indicate that the presence of conspecific larvae or juveniles has a minor influence on aggregated settlement patterns in this species and that other factors are more important. However, in a recent study of contact and settlement rates on smooth Plexiglas panels performed over larger spatial and temporal scales we noticed that settlement rate was significantly correlated to contact rate (Jonsson et al. 2004). Lack of a relationship in the present study may indicate that replication was insufficient to detect an effect. There is also the possibility that settlement decreased when recruits occupied a certain amount of the substrata. For instance, Chabot \& Bourget (1988) working with Semibalanus balanoides found a positive relationship between settlement rate and recruit density until approximately $30 \%$ of the free space was covered, after which settlement rate decreased, with the relationship disappearing at higher densities. A similar result was obtained by Raimondi (1990), who reported that recently settled Chthamalus anisopoma appeared to inhibit further settlement after $14 \mathrm{~d}$ in the field.

Our finding that almost one-third of the cyprids encountering the untreated panels finally settled indicates that they perceived the smooth Plexiglas panels as a suitable substrate (Fig. 5). Walters (1992), Lemire \& Bourget (1996) and Walters et al. (1999) obtained similar recruitment percentages after substrate contact for Balanus amphitrite, Balanus sp. and B. amphitritet, respectively (approximately 100, 25 and 18\%, respectively), while Hills et al. (2000) and Matsumura et al. (2000) observed a much lower proportion of settlement for Semibalanus balanoides cyprids in short-term fieldbased behavioural studies $(<1 \%$ settled during $30 \mathrm{~min}$ recording intervals). The high propensity for settlement on smooth substrata explains the dominant role of $B$. improvisus as a fouling organism on boat hulls in the Baltic, Kattegatt and Skagerrak Seas.

Only in laboratory studies of larval behaviour in still water did we find a clear effect of crude extract prepared from an homogenate of adult tissue. Cyprids appeared more inclined to make contact and explore substrata treated with adult extract than when no conspecific cue was present. This stimulating effect of adult extract was, however, not found in field and laboratory settlement experiments. Recruitment and settlement remained unaffected by different preparations and concentrations of adult extract compared to untreated substrata. Our results on conspecific extracts are in contrast with a previous laboratory study on Balanus improvisus (Dineen \& Hines 1992), and with several studies on other barnacle species in which the presence of chemical extracts from adult conspecifics induced strong gregarious settlement, e.g. Semibalanus balanoides and Elminius modestus (Knight-Jones 1953, Crisp \& Meadows 1962), B. amphitrite (Rittschof et al. 1984), Chthamalus anisopoma (Raimondi 1988a), C. montagui (Whillis et al. 1990), B. crenatus (Miron et al. 1996) and E. covertus (Wright \& Boxshall 1999). The comparably weak response to conspecific extracts shown by $B$. improvisus suggests an opportunistic strategy whereby this barnacle readily colonises newly opened substrata. The lack of a detectable response could be an artifact, since the cues experienced under natural conditions will, at best, be a subset of extracts from adults (Zimmer \& Butman 2000). The use of whole-barnacle extract is an established method used in many recent studies to produce conspecific cues (e.g. Jarrett 1997, Hills et al. 1998, 2000, Matsumura et al. 1998a) with no or few equivocal results. Furthermore, Dineen \& Hines (1992) have previously shown that $B$. improvisus cyprids are stimulated to settle by extracts from whole conspecific and congeneric adults prepared as described by Rittschof et al. (1984). Nevertheless, preparation of chemical extracts from whole adults is a coarse method for assessing conspecific cues. For B. amphitrite, a settlement-inducing protein complex (SIPC) has been identified and purified (Matsumura et al. 1998b), and future work may reveal similar cues for other barnacles. In contrast to the results 
presented here, recent results in the field (Jonsson et al. 2004) and laboratory (Head et al. 2004) indicate that gregarious settlement is present in $B$. improvisus but may be induced by cues from cyprids or juveniles. Such cyprid-cyprid interactions have been shown to stimulate settlement in S. balanoides (Yule \& Walker 1985), B. amphitrite (Clare et al. 1994) and B. improvisus (Head et al. 2004). It may be speculated that a finetuned response to different conspecific life-stages in the neighbourhood could be used to optimise the fitness of a settler. An opportunistic strategy based on colonisation of newly opened space may select for cyprid-cyprid interactions that ensure future copulation in ephemeral populations. Cyprid-adult interactions are expected to be stronger in more long-lived populations, where the presence of adults indicates high-quality habitats.

The results of this study suggest that the pattern of recruitment in the barnacle Balanus improvisus may reflect larval behaviour, whereby responses to different physical and biological cues determine final settlement choice. Local conditions may influence responses in larval behaviour and subsequently determine the final recruitment pattern. Behaviour may change the proportion of settled individuals through active rejection based on chemical cues and surface texture. In contrast to previous studies, the present study suggests that conspecific adult chemical attractants are a minor cue for aggregated settlement of $B$. improvisus. Instead, we propose that rejection of unsuitable substrata may be an important factor driving aggregations of settlement in $B$. improvisus on adjacent substrata that are suitable for settlement. Our results, linking rejection behaviour to aggregated recruitment, support the hypothesis of Hui \& Moyse (1987) that rejection leads to an increased local pool of settling cyprids available for acceptable substrata.

Acknowledgements. Financial support for the study was provided through the MASTEC programme by the Swedish Foundation for Strategic Research, by the Tjärnö Centre of Excellence through the European Union, ERDF, and by MISTRA through the Marine Paint program.

\section{LITERATURE CITED}

Berntsson KM, Jonsson PR (2003) Temporal and spatial patterns in recruitment and succession of a temperate marine fouling assemblage: a comparison between static panels and boat hulls during the boating season. Biofouling 19: 187-195

Berntsson KM, Jonsson PR, Lejhall M, Gatenholm P (2000a) Analysis of behavioural rejection of micro-textured surfaces and implications for recruitment by the barnacle Balanus improvisus. J Exp Mar Biol Ecol 251:59-83

Berntsson KM, Andreasson H, Jonsson PR, Larsson L, Ring K, Petronis S, Gatenholm P (2000b) Reduction of barnacle recruitment on micro-textured surfaces: analysis of effec- tive topographic characteristics and evaluation of skin friction. Biofouling 16:245-261

Bertness MD, Gaines SD, Wahle RA (1996) Wind-driven settlement patterns in the acorn barnacle Semibalanus balanoides. Mar Ecol Prog Ser 137:103-110

Bovet P, Benhamou S (1988) Spatial analysis of animals movements using a correlated random walk model. J Theor Biol 131:419-433

Chabot R, Bourget E (1988) Influence of substratum heterogeneity and settled barnacle density on the settlement of cypris larvae. Mar Biol 97:45-56

Clare AS (1995) Chemical signals in barnacles: old problems, new approaches. Crustac Iss 10:49-67

Clare AS, Freet RK, McClary M Jr (1994) On the antennular secretion of the cyprid of Balanus amphitrite, and its role as a settlement pheromone. J Mar Biol Assoc UK 74: 243-250

Crisp DJ (1974) Factors influencing the settlement of marine invertebrate larvae. In: Grant PT, Mackie AM (eds) Chemoreception in marine organisms. Academic Press, London, p 177-265

Crisp DJ, Barnes H (1954) The orientation and distribution of barnacles at settlement with particular reference to surface contour. J Anim Ecol 23:142-162

Crisp DJ, Meadows PS (1962) The chemical basis of gregariousness in cirripedes. Proc R Soc Lond B 156:500-520

de Nys R, Steinberg PD, Willemsen P, Dworjanyn SA, Gabelish CL, King RJ (1995) Broad spectrum effects of secondary metabolites from the red alga Delisea pulchra in antifouling assays. Biofouling 8:259-271

Dineen JF, Hines AH (1992) Interactive effects of salinity and adult extract upon settlement of the estuarine barnacle Balanus improvisus. J Exp Mar Biol Ecol 156:239-252

Eckman JE, Savidge WB, Gross TF (1990) Relationship between duration of cyprid attachment and drag forces associated with detachment of Balanus amphitrite cyprids. Mar Biol 107:111-118

Foster BA (1987) Barnacle ecology and adaptation. Crustac Iss 5:113-133

Gaines S, Brown S, Roughgarden J (1985) Spatial variation in larval concentrations as a cause of spatial variation in settlement for the barnacle, Balanus glandula. Oecologia 67: $267-272$

Gustafsson B, Stigebrandt A (1996) Dynamics of the freshwater influenced surface layers in the Skagerrak. J Sea Res 35:39-53

Head RM, Berntsson KM, Dahlström M, Overebeke K, Thomason JC (2004) Gregarious settlement in cypris larvae: the effects of cyprid age and assay duration. Biofouling (in press)

Hills JM, Thomason JC, Milligan JL, Richardson M (1998) Do barnacle larvae respond to multiple settlement cues over a range of spatial scales? Hydrobiologia 375/376:101-111

Hills JM, Thomason JC, Davis H, Köhler J, Millett E (2000) Exploratory behaviour of barnacle larvae in field conditions. Biofouling 16:171-179

Holm ER (1990) Attachment behavior in the barnacle Balanus amphitrite (Darwin): genetic and environmental effects. J Exp Mar Biol Ecol 135:85-98

Hui E, Moyse J (1987) Settlement patterns and competition for space. In: Southward AJ (ed) Barnacle biology. Balkema, Rotterdam, p 363-376

Jarrett JN (1997) Temporal variation in substratum specificity of Semibalanus balanoides cyprids. J Exp Mar Biol Ecol 211:103-114

Jonsson PR, Berntsson KM, Larsson AI (2004) Linking larval supply to recruitment: flow-mediated control of initial 
adhesion of barnacle larvae. Ecology (in press)

Knight-Jones EW (1953) Laboratory experiments on gregariousness during setting in Balanus balanoides and other barnacles. J Exp Biol 30:584-598

Lagersson NC, Høeg JT (2002) Settlement behavior and antennulary biomechanics in cypris larvae of Balanus amphitrite. Mar Biol 141:513-526

Lemire M, Bourget E (1996) Substratum heterogeneity and complexity influence microhabitat selection of Balanus sp. and Tubularia crocea larvae. Mar Ecol Prog Ser 135:77-87

Le Tourneux F, Bourget E (1988) Importance of physical and biological settlement cues used at different spatial scales by the larvae of Semibalanus balanoides. Mar Biol 97: $57-66$

Maki JS, Rittschof D, Costlow JD, Mitchell R (1988) Inhibition of attachment of larval barnacles, Balanus amphitrite, by bacterial surface films. Mar Biol 97:199-206

Matsumura K, Mori S, Nagano M, Fusetani N (1998a) Lentil lectin inhibits adult extract induced settlement of the barnacle, Balanus amphitrite. J Exp Zool 280:213-219

Matsumura K, Nagano M, Fusetani N (1998b) Purification of a larval settlement inducing protein complex (SIPC) of the barnacle, Balanus amphitrite. J Exp Zool 281:12-20

Matsumura K, Hills JM, Thomason PO, Thomason JC, Clare AS (2000) Discrimination at settlement in barnacles: laboratory and field experiments on settlement behaviour in response to settlement-inducing protein complexes. Biofouling 16:181-190

Minchinton TE, Scheibling RE (1991) The influence of larval supply and settlement on the population structure of barnacles. Ecology 72:1867-1879

Miron G, Bourget E, Archambault P (1996) Scale of observation and distribution of adult conspecifics: their influence in assessing passive and active settlement mechanisms in the barnacle Balanus crenatus. J Exp Mar Biol Ecol 201: $137-158$

Mullineaux LS, Butman CA (1991) Initial contact, exploration and attachment of barnacle (Balanus amphitrite) cyprids settling in flow. Mar Biol 110:93-104

Pawlik JR (1992) Chemical ecology of the settlement of benthic marine invertebrates. Oceanogr Mar Biol Annu Rev 30:273-335

Pineda J, Caswell H (1997) Dependence of settlement rate on suitable substrate area. Mar Biol 129:541-548

Raimondi PT (1988a) Settlement cues and determination of the vertical limit of an intertidal barnacle. Ecology 69: 400-407

Raimondi PT (1988b) Rock type affects settlement, recruitment, and zonation of the barnacle Chthamalus anisopoma Pilsbry. J Exp Mar Biol Ecol. 123:253-268

Raimondi PT (1990) Patterns, mechanisms, consequences of

Editorial responsibility: Otto Kinne (Editor),

Oldendorf/Luhe, Germany variability in settlement and recruitment of an intertidal barnacle. Ecol Monogr 60:283-310

Raimondi PT, Morse AN (2000) The consequences of complex larval behavior in a coral. Ecology 81:3193-3211

Rittschof D, Branscomb AS, Costlow JD (1984) Settlement and behavior in relation to flow and surface in larval barnacles, Balanus amphitrite Darwin. J Exp Mar Biol Ecol 82: 131-146

Rittschof D, Hooper IR, Branscomb ES, Costlow JD (1985) Inhibition of barnacle settlement and behavior by natural products from whip corals, Leptogornia virgulata. J Chem Ecol 11:551-563

Roberts D, Rittschof D, Holm E, Schmidt AR (1991) Factors influencing initial larval settlement: temporal, spatial and surface molecular components. J Exp Mar Biol Ecol 150: 203-222

Schlichting H (1979) Boundary layer theory, 7th edn. McGraw-Hill, New York

Sugihara G, May RM (1990) Applications of fractals in ecology. Trends Ecol Evol 5:79-86

Toonen R, Pawlik J (1994) Foundations of gregariousness. Nature 370:511-512

Walters LJ (1992) Field settlement locations on subtidal marine hard substrata: is active larval exploration involved? Limnol Oceanogr 37:1101-1107

Walters LJ, Wethey DS (1996) Settlement and early post-settlement survival of sessile marine invertebrates on topographically complex surfaces: the importance of refuge dimensions and adult morphology. Mar Ecol Prog Ser 137:161-171

Walters LJ, Miron G, Bourget E (1999) Endoscopic observations of invertebrate larval substratum exploration and settlement. Mar Ecol Prog Ser 182:95-108

Wethey DS (1986) Ranking of settlement cues by barnacle larvae: influence of surface contour. Bull Mar Sci 39:393-400

Whillis JA, Yule AB, Crisp DJ (1990) Settlement of Chthamalus montagui Southward cyprids on barnacle arthropodin. Biofouling 2:95-99

Winer BJ, Brown DR, Michels KM (1991) Statistical principles in experimental design. McGraw-Hill, New York

Wright JR, Boxshall AJ (1999) The influence of small-scale flow and chemical cues on the settlement of two congeneric barnacle species. Mar Ecol Prog Ser 183:179-187

Yule AB, Walker G (1985) Settlement of Balanus balanoides: the effect of cyprid antennular secretion. J Mar Biol Assoc UK 65:707-712

Zimmer RK, Butman CA (2000) Chemical signaling processes in the marine environment. Biol Bull (Woods Hole) 198: 168-187

Zimmer-Faust RK, Tamburri MN (1994) Chemical identity and ecological implications of a waterborne, larval settlement cue. Limnol Oceanogr 39:1075-1087

Submitted: February 19, 2003; Accepted: March 9, 2004

Proofs received from author(s): June 2, 2004 